\title{
Conversion of Kelp Debris and Faecal Material from the Mussel Aulacomya ater by Marine Micro- Organisms
}

\author{
V. Stuart ${ }^{1}$, R. C. Newell ${ }^{2}$ and M. I. Lucas ${ }^{2}$ \\ 1 Department of Zoology, University of Cape Town, Rondebosch, South Africa \\ ${ }^{2}$ Institute for Marine Environmental Research, Prospect Place, Plymouth PL1 3DH, United Kingdom
}

\begin{abstract}
Freshly powdered kelp debris from Laminaria pallida is characterised by a high C/N ratio of approximately 8.0, whereas material which has passed through the gut of the dominant kelp bed suspension-feeding bivalve Aulacomya ater has a reduced carbon content and a C/N ratio of 4.8. This suggests that Aulacomya ater may derive a substantial proportion, possibly amounting to as much as $40-50 \%$ of its carbon requirements by absorption of the more labile carbon components of its diet whereas the more refractory components are returned to the environment as faeces. Both freshlyfragmented kelp debris and faecal material are colonised by bacteria which are subsequently replaced by flagellates and ciliates whose biomass commonly reaches approximately $10 \%$ of that of the bacterial prey density. Calculation of the conversion efficiency of carbon into the carbon equivalent of bacterial biomass suggests that an efficiency of $10-15 \%$ is achieved by the bacteria which colonise particulate debris, irrespective of the fact that the faecal material may be different in composition from that of freshly-fragmented kelp. Approximately $85-90 \%$ of the fragmented kelp which is not consumed by the filter-feeders and the processed faecal material in the water column is mineralised within $33 \mathrm{~d}$ at $10^{\circ} \mathrm{C}$. The residial $10-15 \%$ assimilated into bacteria could represent a potential food resource for the consumer community. Because of the relatively low conversion of particulate carbon into bacteria, however, it is suggested that their trophic significance as a carbon resource is likely to be small in coastal waters.
\end{abstract}

\section{INTRODUCTION}

The production of uncompacted surface layers of faecal material by both suspension and deposit-feeding organisms has been widely studied and can be remarkably high in some dense communities of deposit-feeders (Rhoads, 1963, 1967; Mangum, 1964; Gordon, 1966; Nicols 1974; Johnson, 1977; Myers $1977 \mathrm{a}, \mathrm{b})$. Rhoads (1967), for example, found that annual defaecation by a community of the polychaete Clymenella torquata can be as high as $54 \mathrm{~kg} \mathrm{~m}^{-2}$. Again, Nichols (1974) showed that annual sediment turnover by the polychaete Pectinaria californiensis reached $8.4 \mathrm{~kg} \mathrm{~m}^{-2}$. Of this, $22.5 \%$ was faecal material whilst the remaining $77.5 \%$ was pseudofaecal; that is, material handled by the worm but not ingested. More recently, Kreuter (1976) estimated the combined processing rate of a mixed community of Littorina irrorata, Arcatula demissa, Polymesoda caroliniana, Uca pugnax and $U$. pugilator on a saltmarsh at Sapelo Island.
Georgia, and showed that the community may deposit $1.7 \mathrm{~kg} \mathrm{~m}^{-2} \mathrm{y}^{-1}$ of which $445 \mathrm{~g}$ is organic material.

Rhoads $(1973,1974)$, Johnson $(1974,1977)$ and Driscoll (1975) have pointed out that deposition of aggregated faecal material and associated permeability changes in the surface layers of sediments may increase the surface available for bacterial colonisation. Organic matter deposited as faeces may also represent a significant proportion of the energy potentially available to consumer invertebrates as a food resource. A recent calculation of energy flow through a kelp bed community suggests, for example, that the energy equivalent of faecal production from the dense community of the mussel Aulacomya ater which dominates the filter-feeding community, is as much as $90 \%$ of the combined production of the macrophytes (Newell et al., unpubl.).

Estimation of the rate of decomposition of such processed material in the sea and, above all, the efficiency of its conversion by marine micro-organisms is central 
to understanding the relative importance of bacteria both in mineralisation and as a potential trophic resource for consumer organisms. Since it has a low density and high water content, and is easily resuspended by even mild turbulence (see also Rhoads, 1963, 1967; McMaster, 1967; Rhoads and Young 1970; Newell, 1979), it is clear that such processed material is potentially available as a food resource for both suspension- and deposit-feeding organisms. The work summarised below follows a series of comparative studies which we have made on the decomposition of algal material in the sea (Newell et al., 1980, 1981; Linley et al., 1981; Lucas et al., 1981; Stuart et al., 1981; reviewed in: Linley and Newell, 1981; Newell and Lucas, 1981) and allows us to make some estimates of the relative significance of macrophytes and processed faecal debris as a source of bacterial production in a kelp bed community.

\section{MATERIAL AND METHODS}

\section{Preparation and Incubation}

Specimens of the mussel Aulacomya ater were collected from a kelp bed at Oudekraal, Cape Peninsula, South Africa, and brought to the laboratory where the shells were cleaned of all debris and epiphytes. They were then placed in a container of $0.45 \mu \mathrm{m}$ filtered seawater overnight. The following morning the water was filtered through a $105 \mu \mathrm{m}$ mesh to remove larger particulate debris, and the faeces collected onto a $53 \mu \mathrm{m}$ filter. In order to prepare particulate debris from kelp, fronds from Laminaria pallida were collected from the kelp bed and transported in an ice-cold container to the laboratory. They were then thoroughly washed to remove epiphytes and mucilage secreted during transport to the laboratory. Eroding tips were then removed from the fronds, freeze-dried and ground in a mill. The powdered detritus was then sieved to obtain particles measuring from $45-63 \mu \mathrm{m}$ in diameter; this size range is similar to the dominant fraction found in seawater collected from the vicinity of the kelp bed (see also Stuart et al., 1981).

A series of six 2-l autoclaved flasks was then set up comprising 3 vessels containing $0.33 \mathrm{~g} \mathrm{l}^{-1}$ freeze-dried powdered Laminaria pallida in 11 freshly collected $53 \mu \mathrm{m}$ filtered seawater, one of the vessels serving as a sterilised control by the addition of a mixture of $7.5 \mathrm{ml}$ chloramphenicol, $7.5 \mathrm{ml}$ erythromycin and $7.5 \mathrm{ml}$ tetracycline from stock solutions containing $10 \mathrm{mg} \mathrm{ml}^{-1}$. A further 3 vessels contained fresh faecal material made up in $1 \mathrm{l}$ of $53 \mu \mathrm{m}$ filtered seawater freshly collected from the kelp bed at Oudekraal, one of the 3 vessels also acting as a sterilised control by the addi- tion of the mixed antibiotics as before. The flasks were sealed with rubber bungs, and $0.2 \mu \mathrm{m}$ Nuclepore-filtered air was drawn first through the control flasks and then through the experimental flasks. The vessels were incubated in a shaking water bath at $10^{\circ} \mathrm{C}$, which is similar to the natural temperature of the kelp bed seawater, and were illuminated with two $20 \mathrm{~W}$ fluorescent tubes.

Samples of $35 \mathrm{ml}$ were removed from the flasks via a sterilised tube in the stopper by means of a sterilised syringe at daily intervals for the first $18 \mathrm{~d}$, and on each third day up to $33 \mathrm{~d}$. Of this sample, $5 \mathrm{ml}$ was used for particle analysis, $10 \mathrm{ml}$ was freeze-dried for carbon and nitrogen analysis, $10 \mathrm{ml}$ fixed with $0.5 \mathrm{ml}$ formalin for epifluorescence microscopy (AODC), and $10 \mathrm{ml}$ fixed with $0.5 \mathrm{ml}$ glutaraldehyde for scanning electron microscopy. Counts made on samples from the sterilised controls showed that the addition of antibiotics resulted in the inhibition of the micro-organisms to approximately one tenth of the numbers in the original seawater inoculum over the duration of the experimental period of $33 \mathrm{~d}$.

\section{Particle Numbers and Size Distribution}

Three $1.0 \mathrm{ml}$ samples of the incubation media were diluted $1: 50$ with $0.2 \mu \mathrm{m}$ Nuclepore filtered seawater. The number of particles was then counted and the size distribution in the channel range 2-15 (4-80.6 $\mu \mathrm{m}$ ) estimated with a Coulter counter (Model TA II) equipped with a $280 \mu \mathrm{m}$ orifice tube. The mean number of counts in each channel was corrected for background counts in $0.2 \mu \mathrm{m}$ filtered seawater. Particle size distribution was expressed in parts per million plotted against the $\log _{10}$ of the mean particle diameter for each channel (Strickland and Parsons, 1972). The size distribution of particles was then plotted as a function of incubation time by means of a multidimensional graphics system (University of Cape Town, Computer Centre)

\section{Carbon and Nitrogen Analysis}

The total carbon and nitrogen content in up to 7 replicate samples of freeze-dried media was measured with a Carlo-Erba Elemental Analyzer (Model 1106) fitted with an integrator to give peak area. Portions of 5-10 mg dried sample were weighed into cleaned, carbon-free tin containers with a Cahn 24 electrobalance and placed in an auto-sampler which deposited each container sequentially into the combustion reactor at $1050^{\circ} \mathrm{C}$. The nitrogen and carbon content of 5-10 blank samples of tin cups alone, and of the experimen- 
tal samples, was then calculated from the mean peak areas of 10 weighed samples of approximately $2.0 \mathrm{mg}$ Cyclohexanone (Carlo Erba) which contains $20.14 \%$ nitrogen and $51.79 \%$ carbon.

\section{Microbial Numbers and Biomass}

The cell numbers were estimated using the acridine orange direct count (AODC) method based on Hobbie et al. (1977) as described by Linley et al. (1981) and as used in previous work on kelp particulate debris (Stuart et al., 1981). Cell dimensions were then estimated from scanning electron micrographs of filtered samples of the incubation media (Linley et al., 1981), and the biomass calculated from the numbers and volumes of the cells, together with estimates of their specific gravity (Calkins and Summers, 1941; Luria, 1960; Doetsch and Cook, 1973; Linley et al., 1981; Stuart et al,, 1981). Although shrinkage of the cells during preparation for scanning electron microscopy can cause an under-estimate of cell volumes (Fuhrman, 1981), we found that in practice shrinkage is rarely in excess of $3-5 \%$ of the linear dimensions; if any preparation showed obvious shrinkage, it was rejected. The extent of shrinkage was calculated from estimates of cell dimensions using light microscopy, epifluorescence techniques and SEM on samples of rods and cocci, and the effects of cell shrinkage on the apparent cell dimensions were regarded as negligible in our preparations. Dry biomass and the carbon equivalent of wet biomass were calculated using the coefficients 0.2 and 0.1 respectively (Luria, 1960; Troitsky and Sorokin, 1967; see also Sorokin and Kadota, 1972).

\section{RESULTS AND DISCUSSION}

\section{Succession and Biomass of Micro-Organisms Associated with Kelp Debris and Faecal Material}

The succession of micro-organisms which colonise kelp mucilage incubated in seawater has been described by Linley et al. (1981), that characteristic of particulate debris by Stuart et al. (1981); see also Linley and Newell (1981), and Newell and Lucas (1981). In both cases, the media were first dominated by bacteria which were replaced by populations of flagellates and ciliates. In the case of particulate debris, choanoflagellates and amoebae also appeared in the later stages of incubation. The succession occurring on faecal material is similar in that the bacterial population, consisting mainly of small rods (Fig. 1a) reaches a maximum of $4.6 \times 10^{7}$ cells ml-1 and is followed by an increase in a population of small phagotrophic flagellates which attain a density of $3.3 \times 10^{5}$ cells $\mathrm{ml}^{-1}$. But in all cases a secondary, and sometimes a tertiary population of bacteria colonises the faecal fragments. The bacteria reach a density of approximately $3.0 \times 10^{7}$ cells $\mathrm{ml}^{-1}$ in these later colonisation phases and are morphologically similar to the initial colonisers, although it seems likely that they are different strains utilising different components of the faecal substrate materials. In the later stages of incubation, a sparsely mixed community of ciliates (Fig. 1b), choanoflagellates (Fig. 1c), amoebae (Fig. 1d) and testaceans (Fig. 1e) developed. After Day 18, the media containing fresh faecal material became dominated by an extremely large population of phototrophic flagellates (Fig. 1f) whose population attained a density of $4-5 \times 10^{5}$ cells $\mathrm{ml}^{-1}$ which is equivalent to a biomass of as much as $33 \mathrm{mg} \mathrm{l}^{-1}$. These organisms showed a red autofluorescence in nonstained preparations and could even be detected in analyses of the particulate matter with a Coulter counter (see p. 52).

The calculated biomass of the heterotrophic components of the population in incubation media containing faecal material and particulate debris is shown in Fig. 2. It is apparent that the calculated dry biomass of initial bacterial colonisers on the faecal material reached a maximum value of $1.8 \mathrm{mg}^{-1}$ as early as Day 2 , after which there was a reduction in biomass following the appearance of grazing flagellates and ciliates. These reached a maximum biomass of approximately $0.8 \mathrm{mg}^{-1}$ before declining, after which a secondary peak of bacterial rods occurred on Day 10 . The bacteria colonising the particulate debris from kelp achieved a biomass similar to that in the faecal material by Day 2, but continued to increase to as much as $5-8 \times 10^{7}$ cells $\mathrm{ml}^{-1}$, or $5.5 \mathrm{mg} \mathrm{l}^{-1}$ by Day 6 , whereupon they declined sharply with the appearance of heterotrophic flagellates and ciliates which achieved a combined biomass of approximately $0.6 \mathrm{mg} \mathrm{l}^{-1}$ Day 10 . The reason for the continued increase in bacterial biomass in the kelp, associated with the later apperance of heterotrophic flagellates and ciliates - compared with the incubation media containing faecal material - is not known, but could be associated both with a greater availability of easily degradable material from the Laminaria (Newell and Lucas, 1981) and possible inhibitory effects of phenolic compounds from the Laminaria mucilage on the protozoans in the incubation media. As in previous work on kelp debris, the maximum biomass of heterotrophic flagellates which are assumed to graze on the bacteria (Fenchel, 1972) is approximately $10 \%$ of that of the bacterial prey density (Linley and Newell, 1981; Linley et al., 1981). It seems likely that' the rather lower initial bacterial biomass found in incubation media containing faecal material reflects the early appearance of flagellates 

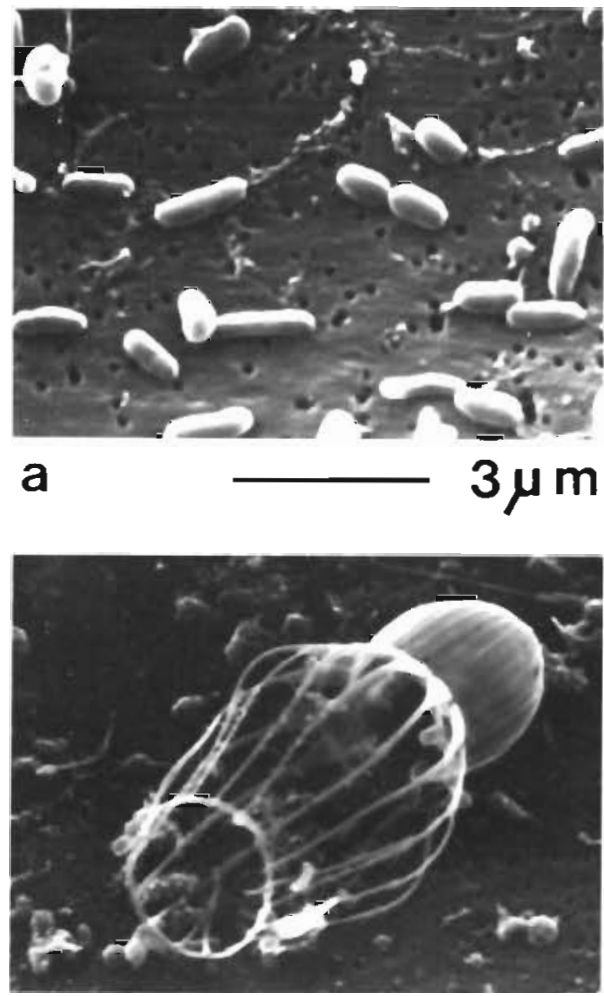

C
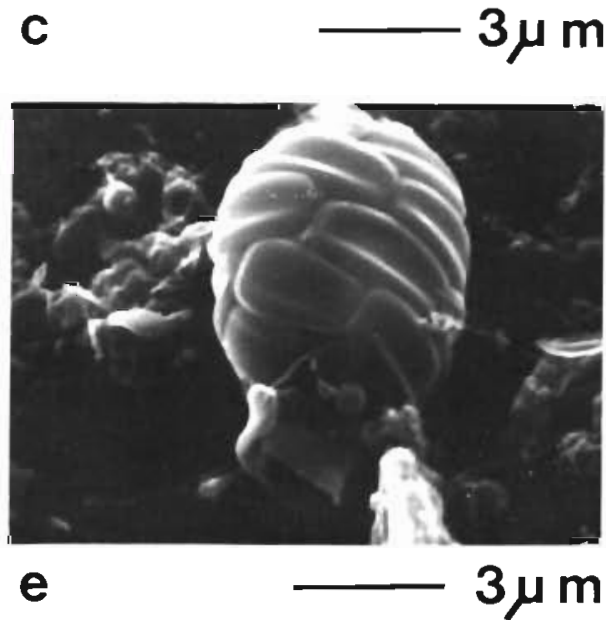
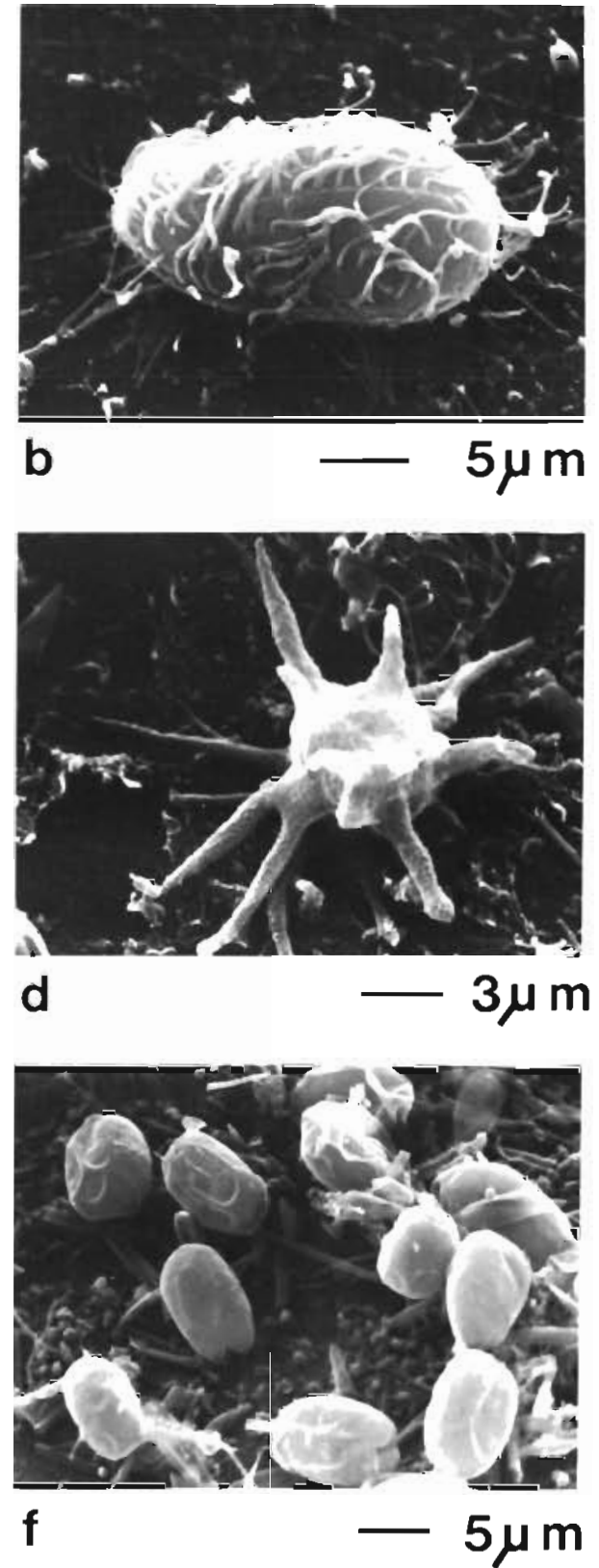

Fig. 1. Microbial communities associated with degradation of faecal debris from the mussel Aulacomya ater. (a) Small rods which initially colonise faecal material; (b) a ciliate; (c) a choanoflagellate; (d) an amoeba; (e) a testacean; (f) phototrophic flagellates, all of which characterise the later incubation phase of faecal material in seawater

rather than the limiting effects of substrate availability for bacterial growth.

\section{Utilisation of Particulate Debris}

The changes in particle concentration (ppm by volume, see p. 48) in incubation media containing kelp particulate debris are plotted as a function of time of incubation at $10^{\circ} \mathrm{C}$ and particle size over the range $4-80.6 \mu \mathrm{m}$ in Fig. 3. This shows the response surface both as a stereodiagram and the corresponding contour diagram projected onto the $\mathrm{X}_{1}, \mathrm{X}_{2}$ axes. It can be seen that the powdered kelp was initially supplied in the range 40-60 $\mu \mathrm{m}$ and that in the non-sterile seawater (Fig. 3a) there was a rapid loss of particles over the first $12 \mathrm{~d}$ of incubation at $10^{\circ} \mathrm{C}$, followed by a more gradual loss and fragmentation into finer particles over the incubation period of $33 \mathrm{~d}$. In contrast, the control series (Fig 3b) showed little evidence of loss aver the first $27 \mathrm{~d}$. After this time some loss and fragmentation of the particles into the finer size range occurred, associated 
Fig. 2. Estimated biomass of bacteria and heterotrophic protozoans in seawater incubated over a period of $33 \mathrm{~d}$ at $10^{\circ} \mathrm{C}$ with faecal material from the mussel $\mathrm{Au}$ lacomya ater (left); powdered Laminaria debris (right)
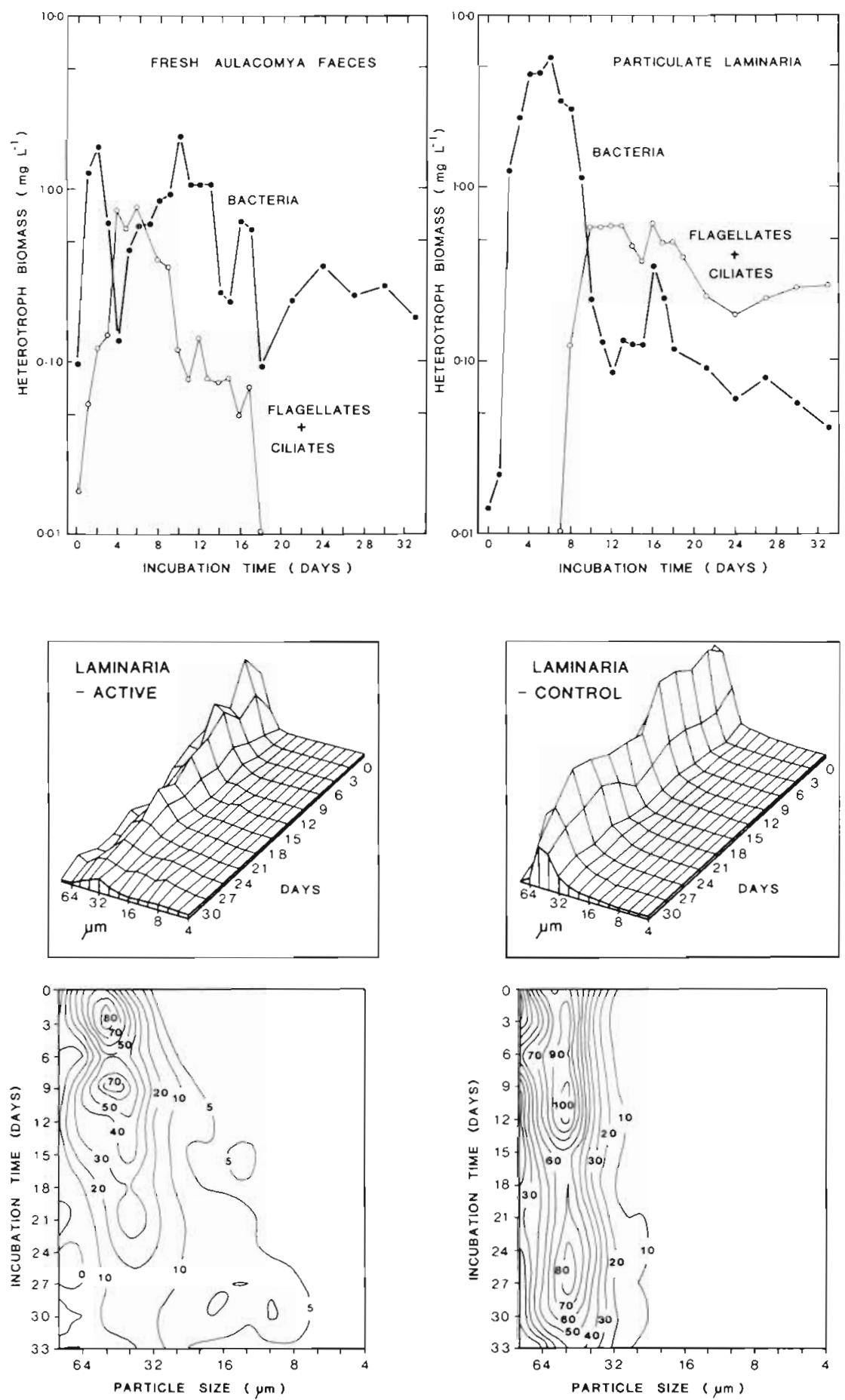

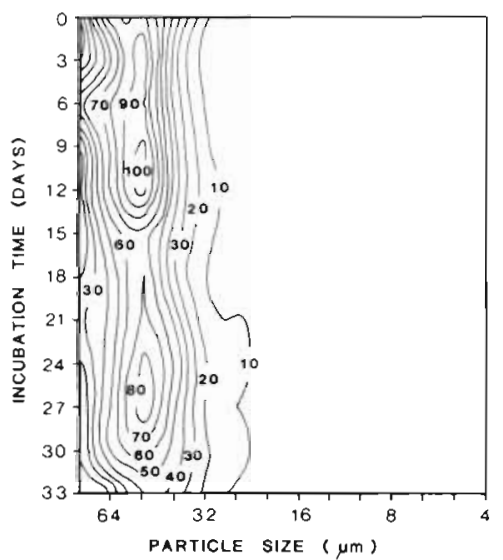

Fig. 3. Response surface diagram showing concentration of powdered Laminaria debris (ppm, by volume) plotted as a function of particle size $\left(x_{1}\right)$ and time of incubation at $10^{\circ} \mathrm{C}\left(x_{2}\right)$. Projection onto $x_{1}, x_{2}$ axes shown as a contour diagram. Left: Non-sterilised seawater; right: sterilised control

with the appearance of bacteria in the control vessels from Day 21 onwards.

The corresponding changes in particle size distribution in seawater containing faecal material incubated for up to $33 \mathrm{~d}$ at $10^{\circ} \mathrm{C}$ are shown in Fig. 4. The size spectrum of the faecal material was in the same range as the particles which occur in the natural kelp bed seawater (see p. 48) and to that of the powdered kelp debris supplied in the incubator experiments. There was again some evidence of loss associated with the appearance of bacteria in the control media after $33 d$ of incubation at $10^{\circ} \mathrm{C}$. In the non-sterilised media, however, utilisation of particulate matter from a maximum of $30-40 \mathrm{ppm}$ in the range $25-50 \mu \mathrm{m}$ to less than 20 ppm occurred by Day 33. The appearance of a large concentration of particles in the size range $5-10 \mu \mathrm{m}$ 

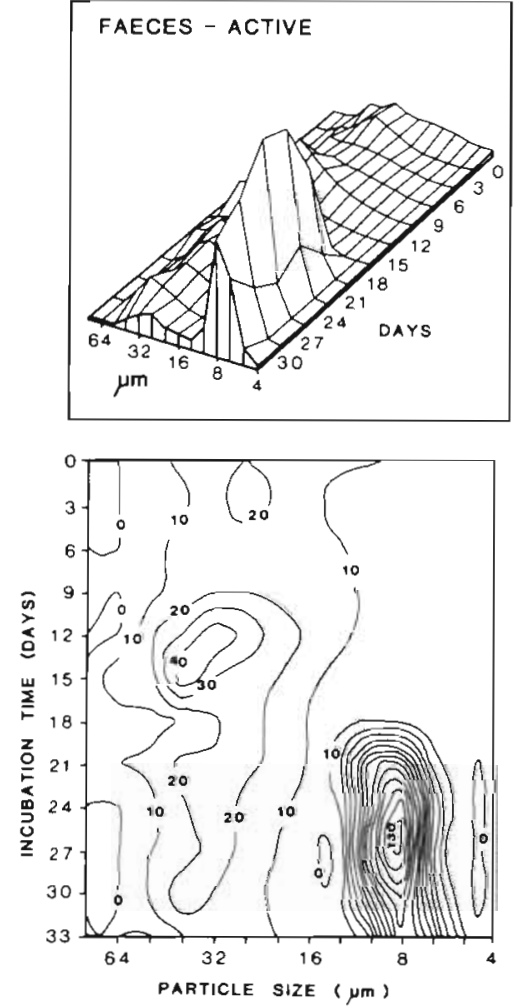
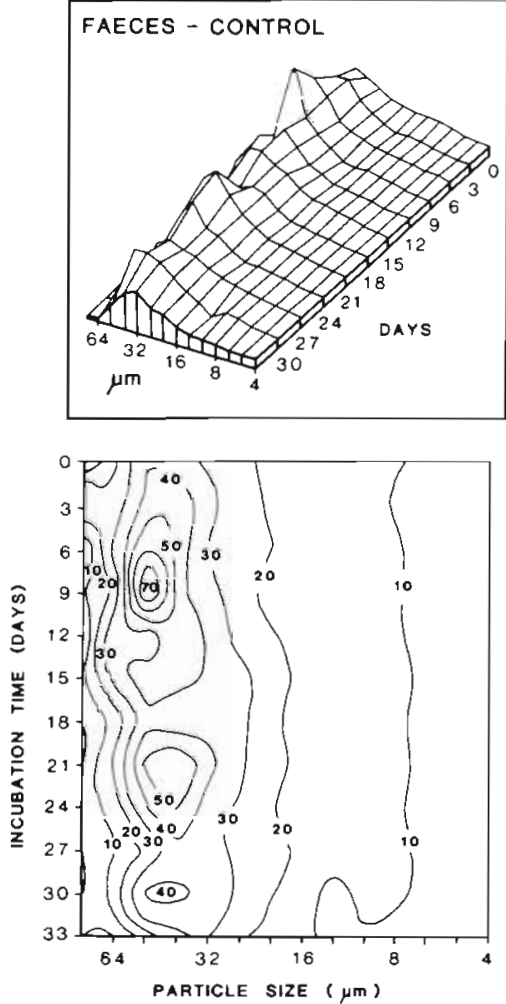

Fig. 4. Response surface diagram showing concentration of faecal material from the mussel Aulacomya ater (ppm, by volume) plotted as a function of particle size $\left(x_{1}\right)$ and time of incubation at $10^{\circ} \mathrm{C}\left(x_{2}\right)$. Projection onto $x_{1}, x_{2}$ axes shown as a contour diagram. Left: Non-sterilised seawater; right: sterilised control diameter reflects the appearance of a population of phototrophic flagellates which colonise the incubation media from Day 21 onwards (see p. 49).

Analysis of the particle-size distribution in media containing powdered Laminaria debris and faecal material incubated in seawater thus suggests that the bacterial population which colonises the media is capable of utilising the particulate component over a period of $33 \mathrm{~d}$ at $10^{\circ} \mathrm{C}$. This gives some indication of the turnover time for particulate debris in the water column. It is, however, probable that the dissolved component of the debris, which is not recorded during analyses of particulate matter, represents an important primary substrate for microbial activity (Newell and Lucas, 1981; Stuart et al., 1981) and has a considerably shorter turnover time than the particulate component (Lucas et al., 1981). It is thus necessary to determine the utilisation of carbon from both particulate and dissolved components of the kelp and faecal substrates in order to quantify the carbon conversion efficiency of organic matter into microbial biomass.

\section{Carbon and Nitrogen Concentration}

The carbon and nitrogen concentrations and $\mathrm{C} / \mathrm{N}$ ratios for powdered kelp debris and faecal material cultured in seawater at $10^{\circ} \mathrm{C}$ are shown in Tables 1 and 2. It is evident that the carbon concentration in the non-sterilised Laminaria debris shows a loss from $111.17 \mathrm{mg} \mathrm{l}^{-1}$ to $67.21 \mathrm{mg} \mathrm{l}^{-1}$ in $10 \mathrm{~d}_{\text {, whereas the }}$ sterilised control series reveal no evidence of a significant loss over the same period. At the same time, there was some evidence of loss of nitrogen in the nonsterilised media, but not in the controls. The $\mathrm{C} / \mathrm{N}$ ratios of the controls thus remained at a mean of $8.16 \pm 0.66$ $\mathrm{S}$. $\mathrm{D}(\mathrm{N}=11)$, whereas those in the non-sterilised experimental media declined from over 8.0 to 5.8 over a period of $10 \mathrm{~d}$ at $10^{\circ} \mathrm{C}$.

The carbon content of the faecal material in the nonsterile seawater also declined from an initial concentration of $63.94 \mathrm{mg} \mathrm{l}^{-1}$ to $45.05 \mathrm{mg} \mathrm{l}^{-1}$ over a period of $10 \mathrm{~d}$, and to $32.70 \mathrm{mg} \mathrm{l}^{-1}$ after $33 \mathrm{~d}$ at $10^{\circ} \mathrm{C}$.

The corresponding nitrogen concentrations were rather similar to those recorded in the powdered kelp debris, but since the carbon content of the faeces was approximately half that in Laminaria debris, the C/N ratios for faecal material range from 4.89 to 2.73 over the $33 \mathrm{~d}$ incubation period. The carbon content of the sterile controls showed no evidence of utilisation, neither was there a significant loss of nitrogen over a period of $10 \mathrm{~d}$. The $\mathrm{C} / \mathrm{N}$ ratio for the sterilised faeces thus remained at a mean of $4.89 \pm 0.24 \mathrm{~S} . \mathrm{D} .(\mathrm{N}=11)$ throughout the incubation period.

The faecal material voided by Aulacomya ater thus represents a resource which has a $\mathrm{C} / \mathrm{N}$ ratio approxi- 
Table 1. Carbon and nitrogen concentration $\left(\mathrm{mg} \mathrm{l}^{-1}\right)$ and $\mathrm{C} / \mathrm{N}$ ratios in cultures containing $0.33 \mathrm{~g} \mathrm{I}^{-1}$ of powdered freeze-dried Laminaria of 45-63 $\mu \mathrm{m}$ particle size, in $53-\mu \mathrm{m}$ filtered seawater from Oudekraal

\begin{tabular}{|c|c|c|c|c|c|c|c|c|c|c|c|c|}
\hline \multirow[b]{2}{*}{ Days } & \multicolumn{6}{|c|}{ Experimental } & \multicolumn{6}{|c|}{ Sterile control } \\
\hline & $\mathrm{n}$ & $\begin{array}{l}\text { Carbon } \\
\left(\mathrm{mg} \mathrm{I}^{-1}\right)\end{array}$ & \pm S.D. & $\begin{array}{l}\text { Nitrogen } \\
\left(\mathrm{mg} \mathrm{l}^{-1}\right)\end{array}$ & \pm S.D. & $\begin{array}{l}\mathrm{C} / \mathrm{N} \\
\text { ratio }\end{array}$ & n & $\begin{array}{l}\text { Carbon } \\
\left(\mathrm{mg} \mathrm{l}^{-1}\right)\end{array}$ & \pm S.D. & $\begin{array}{l}\text { Nitrogen } \\
\left(\mathrm{mg} \mathrm{l}^{-1}\right)\end{array}$ & $\pm S . D$ & $\begin{array}{l}\mathrm{C} / \mathrm{N} \\
\text { ratio }\end{array}$ \\
\hline 0 & 6 & 111.17 & 14.5 & 13.81 & 1.5 & 8.05 & 4 & 110.44 & 1.1 & 15.22 & 0.0 & 7.26 \\
\hline 1 & 6 & 109.72 & 7.6 & 12.71 & 1.8 & 8.63 & 4 & 115.16 & 3.3 & 14.71 & 1.1 & 7.83 \\
\hline 2 & 6 & 93.37 & 16.7 & 11.62 & 4.4 & 8.04 & 4 & 116.62 & 4.7 & 15.22 & 0.0 & 7.66 \\
\hline 3 & 6 & 97.36 & 15.3 & 14.53 & 0.0 & 6.70 & 4 & 112.25 & 0.7 & 15.99 & 1.1 & 7.02 \\
\hline 4 & 6 & 82.47 & 5.4 & 11.99 & 3.6 & 6.88 & 4 & 110.44 & 3.6 & 13.44 & 1.1 & 8.22 \\
\hline 5 & 5 & 74.11 & 4.0 & 12.35 & 1.8 & 6.00 & 5 & 111.16 & 3.3 & 13.44 & 1.1 & 8.27 \\
\hline 6 & 8 & 79.93 & 10.5 & 12.35 & 2.5 & 6.47 & 5 & 108.26 & 5.1 & 13.07 & 0.7 & 8.28 \\
\hline 7 & 7 & 72.66 & 8.0 & 10.54 & 1.5 & 6.89 & 4 & 107.50 & 6.9 & 12.71 & 0.0 & 8.46 \\
\hline 8 & 6 & 69.75 & 11.6 & 9.81 & 4.0 & 7.11 & 4 & 110.80 & 5.1 & 12.35 & 1.1 & 8.97 \\
\hline 9 & 6 & 68.30 & 8.0 & 9.81 & 4.4 & 6.96 & 4 & 109.40 & 1.5 & 12.35 & 1.1 & 8.86 \\
\hline 10 & 6 & 67.21 & 9.8 & 11.63 & 4.7 & 5.78 & 4 & 119.90 & 2.2 & 13.44 & 1.1 & 8.92 \\
\hline
\end{tabular}

Table 2. Carbon and nitrogen concentration $\left(\mathrm{mg} \mathrm{l}^{-1}\right)$ and $\mathrm{C} / \mathrm{N}$ ratio in cultures containing fresh faecal material from the mussel Aulacomya ater in 53- $\mu \mathrm{m}$ filtered seawater from Oudekraal

\begin{tabular}{|c|c|c|c|c|c|c|c|c|c|c|c|c|}
\hline \multirow[b]{2}{*}{ Days } & \multicolumn{6}{|c|}{ Experimental } & \multicolumn{6}{|c|}{ Sterile control } \\
\hline & $\mathrm{n}$ & $\begin{array}{l}\text { Carbon } \\
\left(\mathrm{mg} \mathrm{l}^{-1}\right)\end{array}$ & $\pm S . D$ & $\begin{array}{l}\text { Nitrogen } \\
\left(\mathrm{mg} \mathrm{l}^{-1}\right)\end{array}$ & \pm S.D. & $\begin{array}{l}\mathrm{C} / \mathrm{N} \\
\text { ratio }\end{array}$ & $\mathrm{n}$ & $\begin{array}{l}\text { Carbon } \\
\left(\mathrm{mg} \mathrm{l}^{-1}\right)\end{array}$ & \pm S.D. & $\begin{array}{c}\text { Nitrogen } \\
\left(\mathrm{mg} \mathrm{l}^{-1}\right)\end{array}$ & \pm S.D. & $\begin{array}{l}\mathrm{C} / \mathrm{N} \\
\text { ratio }\end{array}$ \\
\hline 0 & 5 & 63.94 & 1.8 & 13.08 & 1.8 & 4.89 & 4 & 62.96 & 0.7 & 13.48 & 0.0 & 4.67 \\
\hline 1 & 5 & 56.67 & 1.8 & 10.90 & 2.5 & 5.20 & 4 & 64.66 & 1.1 & 13.48 & 0.0 & 4.80 \\
\hline 2 & 5 & 50.86 & 2.5 & 10.90 & 2.5 & 4.67 & 4 & 64.67 & 1.1 & 12.13 & 1.5 & 5.33 \\
\hline 3 & 5 & 44.32 & 4.7 & 10.17 & 1.5 & 4.36 & 4 & 62.49 & 1.1 & 12.93 & 1.3 & 4.83 \\
\hline 4 & 5 & 50.14 & 2.9 & 10.90 & 2.5 & 4.60 & 4 & 63.58 & 0.7 & 12.93 & 2.5 & 4.92 \\
\hline 5 & 5 & 42.14 & 1.8 & 10.17 & 1.5 & 4.14 & 4 & 62.85 & 0.7 & 13.48 & 0.0 & 4.66 \\
\hline 6 & 5 & 44.32 & 1.5 & 10.90 & 2.5 & 4.03 & 4 & 63.21 & 1.1 & 13.48 & 0.0 & 4.69 \\
\hline 7 & 5 & 47.96 & 4.0 & 10.17 & 2.9 & 4.72 & 4 & 64.67 & 1.1 & 12.93 & 1.3 & 5.00 \\
\hline 8 & 5 & 46.50 & 8.0 & 9.44 & 1.8 & 4.93 & 4 & 64.67 & 1.1 & 12.13 & 1.5 & 5.33 \\
\hline 9 & 5 & 45.78 & 6.2 & 10.17 & 1.5 & 4.50 & 4 & 64.67 & 0.7 & 13.48 & 0.0 & 4.80 \\
\hline 10 & 5 & 45.05 & 6.2 & 10.17 & 1.5 & 4.43 & 4 & 63.94 & 0.0 & 13.48 & 0.0 & 4.74 \\
\hline 11 & 4 & 41.05 & 1.5 & 10.90 & 0.0 & 3.77 & - & - & - & - & - & - \\
\hline 12 & 4 & 39.96 & 0.0 & 10.90 & 0.0 & 3.67 & - & - & - & - & - & - \\
\hline 14 & 3 & 39.96 & 0.0 & 10.90 & 0.0 & 3.67 & - & - & - & - & - & - \\
\hline 33 & 3 & 32.70 & 0.0 & 11.99 & 1.8 & 2.73 & - & - & - & - & - & - \\
\hline
\end{tabular}

Fig. 5. Concentration of total carbon in sterile control flasks and non-sterilised media as a function of time of incubation at $10^{\circ} \mathrm{C}$. Carbon content of the added antibiotic has been subtracted from controls. Left: Fresh faecal material from the mussel Aulacomya ater; right: powdered debris from the kelp Laminaria pallida. Data summarised from Tables 1 and 2
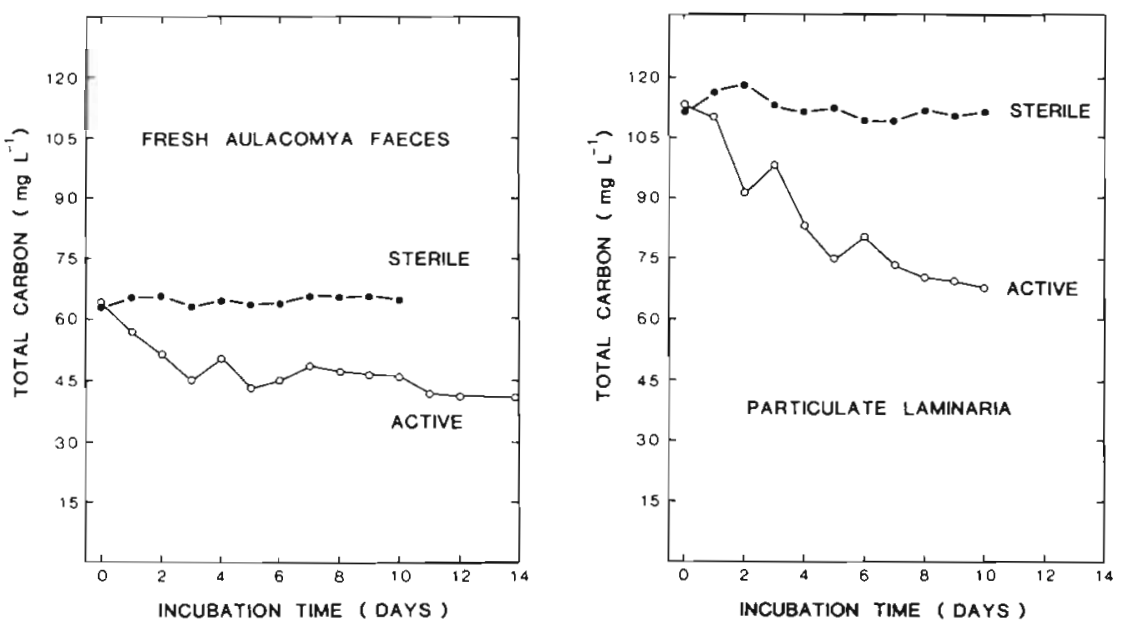
mately half that of freshly powdered Laminaria debris, but the actual concentrations of nitrogen are similar in both. The main implication is that a good deal of the carbon from particulate matter ingested by the mussel (possibly amounting to $40-50 \%$ ) may be utilised during passage through the gut, leaving a more refractory carbon component to be degraded by the bacteria which colonise the faeces. Bacterial colonisation of the faeces then results in a further reduction in the $\mathrm{C} / \mathrm{N}$ ratio from approximately 4.8 to 2.7 over a period of $33 \mathrm{~d}$ at $10^{\circ} \mathrm{C}$ and reflects utilisation of carbon necessary to support the microheterotrophic community rather than an increase in the absolute nitrogen concentration of the faecal material itself.

The net utilisation of carbon associated with the development of a known biomass of microheterotrophs may be obtained from the difference between the carbon concentration in the sterile control and non-sterile experimental flasks. These values are summarised in Fig. 5 which shows that the principal carbon losses occurred over the first $6-8 \mathrm{~d}$ and probably reflect utilisation of dissolved components of both faecal and particulate kelp debris (see also Stuart et al, 1981). Further losses occurred more slowly, especially from the powdered kelp debris, and are likely to correspond with the utilisation of particulate matter noted on p. 52 (see also Fig. 3).

\section{Carbon Conversion Efficiency}

The net utilisation of carbon and the corresponding increase in the carbon equivalent of bacterial biomass is shown as a function of incubation time at $10^{\circ} \mathrm{C}$ in Fig. 6. Clearly, during the logistic phase of bacterial growth, up to the time the bacterial biomass was limited by the grazing activity of flagellates (p. 49), the utilisation of carbon from the substrate can be directly equated to the carbon equivalent of bacterial biomass. The value of bacterial carbon/net carbon utilised from the debris $\times 100$ then gives the percent 'carbon conversion efficiency' of the primary microbial colonisers in the system (see also Lucas et al., 1981; Newell and Lucas, 1981; Newell et al., 1981).

The fact that the fresh faecal material showed 2 phases of bacterial growth allows a calculation of the carbon conversion efficiency for both the initial phase of utilisation of dissolved organic carbon from Days $0-2$, and the utilisation of carbon from the particulate component from Days 4-10. These data, together with those for the particulate kelp up to the bacterial maximum at Day 6, are shown in Fig. 7. In each case, as we have noted previously (Newell and Lucas, 1981; Stuart et al., 1981), the curves are somewhat sigmoid in form with an initial phase of relatively high carbon utilisation with a small increase in bacterial carbon. This is followed by an exponential phase of bacterial growth where the increase in bacterial carbon per unit carbon used is high. The carbon conversion efficiency is thus higher after this initial phase of colonisation and carbon utilisation, and in general approaches values recorded by Payne (1970) for specific strains of bacteria grown on single substrates. However, in the context of conversion of mixed substrates by heterogeneous natural populations of bacteria in seawater it seems more meaningful to express the conversion efficiency in terms of overall utilisation of carbon from initial colonisation to the time of maximal bacterial biomass.

The equations for the regressions for the fresh faecal material are: $Y=0.086+0.063 X_{i} r=0.987(\mathrm{~N}=3)$ for the brief initial phase of colonisation between Days 0 and 2 , and $Y=0.0213+0.237 X_{i} r=0.7869(\mathrm{~N}=7)$ for the second phase of bacterial growth between Days 4 and 10 . The carbon conversion efficiencies for the 2 phases of faecal material are thus $6.3 \%$ and $23.7 \%$ with a mean of $15 \%$. Equally, the corresponding equation for carbon conversion of powdered particulate material is $Y=-0.440+0.0911 X: r=0.9534(\mathrm{~N}=7)$, which yields a carbon conversion efficiency of $9.1 \%$. These values are within the range reported for both
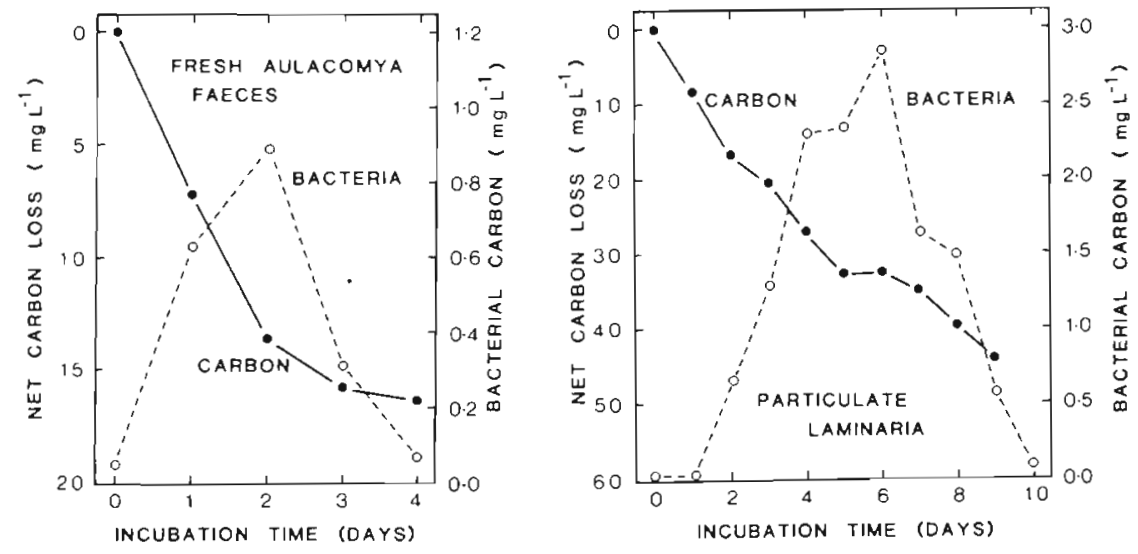

Fig. 6. Net utilisation of carbon and synchronous increase in carbon equivalent of bacterial biomass as a function of time of incubation in seawater at $10^{\circ} \mathrm{C}$. Left: Fresh faecal material from the mussel Aulacomya ater; right: powdered debris from the kelp Laminaria pallida. Carbon equivalent of bacterial biomass was estimated as $50 \%$ of dry biomass (see Luria, 1960 and p. 49) 
Fig. 7 . Increase in bacterial carbon (in seawater at $10^{\circ} \mathrm{C}$ ) as a function of net carbon utilised from incubation media containing fresh faecal material from the mussel Aulacomya ater (left); powdered debris from the kelp Laminaria pallida (right)
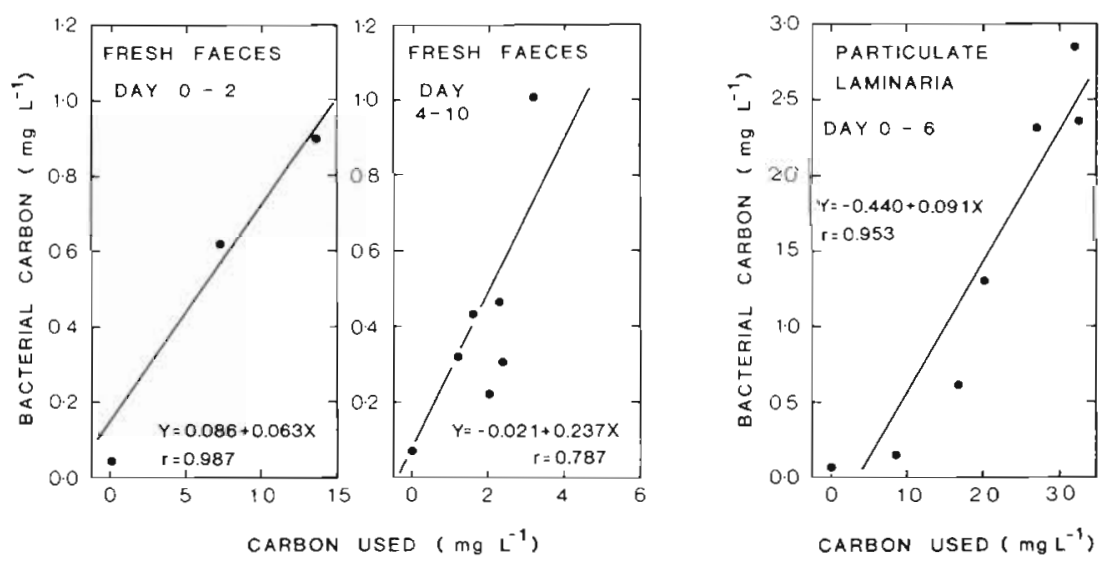

dissolved and particulate components of kelp debris. Lucas et al. (1981) for example, reported equivalent carbon: carbon conversion values of from 6-15\%, depending on season, for the conversion of mucilage released during fragmentation of the kelps Laminaria pallida and Ecklonia maxima. Again, Stuart et al. (1981) found a maximum of $30 \%$ for the carbon conversion efficiency during the logistic phase of bacterial utilisation of dissolved matter, but a much lower value of only $5-6 \%$ for the conversion of particulate matter. Since the particulate matter comprises $70 \%$ of the fragmented material whilst the dissolved component comprises only $30 \%$ (Hatcher et al., 1977; Johnston et al., 1977; Newell et al., 1980) the overall conversion for the mixed debris would be $13.2 \%$

These results suggest, therefore, that a carbon conversion efficiency of approximately $10-15 \%$ is achieved by bacteria which colonise particulate debris irrespective of $j$ ts origin or the fact that faecal material which has been processed through the gut of consumer organisms may be different in composition from that of freshly fragmented particulate kelp

\section{CONCLUSIONS}

The trophic significance of bacterial conversion of faecal matter for consumer organisms has been widely recognised (Newell, 1965; Darnell, 1967; Odum and De La Cruz, 1967; Fenchel, 1972; Sieburth, 1976; Tenore 1976), but it is only comparatively recently that it has become possible to equate the bacterial biomass which is potentially available as a food resource to the requirements of the consumer organisms. Such estimates can be made not only from the biomass of microorganisms available in the environment near to consumer organisms (Cammen, 1980), but also from the bacterial production which can be supported from degradation of the products of primary production (Newell et al, unpubl.).

The results presented here show that freshly pow- dered kelp debris from Laminaria pallida is characterised by a high $\mathrm{C} / \mathrm{N}$ ratio of approximately 8.0 whereas material which has passed through the gut of the dominant kelp bed suspension-feeding bivalve Aulacomya ater, suffers a relative reduction in carbon, bringing the $\mathrm{C} / \mathrm{N}$ ratio to 4.8 . This suggests that $A$. ater may derive approximately $40-50 \%$ of its carbon requirements by absorption of the more labile components of its diet, whereas the more refractory carbon compounds are returned to the environment with the faeces. Both freshly fragmented kelp debris and faecal material are subsequently colonised by bacteria which are then replaced by flagellates and ciliates, whose biomass commonly reaches approximately $10 \%$ of that of their bacterial prey.

Calculation of the conversion efficiency of particulate carbon into bacterial carbon suggests that an efficiency of $10-15 \%$ is achieved by the bacteria colonising both particulate carbon from kelp and processed faecal material from Aulacomya ater. Approximately 85-90\% of the fragmented kelp which is not consumed by the filter-feeders and particulate faecal material in the water column is thus mineralised over a period of $33 \mathrm{~d}$ at $10^{\circ} \mathrm{C}$. The residual $10-15 \%$ assimilated into bacteria could represent a potential food resource for further processing by the consumer community. Since it has been estimated that the energetic contribution of processed material of faecal origin from consumer organisms is similar to that of the combined primary production of the macrophytes in kelp beds of the southern Cape Peninsula (Newell et al., unpubl.), it follows that bacterial production from faeces is comparable in significance to that based on the direct decomposition of fragmented macrophyte debris. In both cases, however, the relatively low conversion of particulate carbon into bacteria suggests that their trophic significance as a carbon resource is likely to be small in coastal waters

Acknowledgements. We wish to express our sincere thanks to Miss Monica Carville for plotting the multidimensional graphs, and to the EM Unit, University of Cape Town, for use 
of their facilities. Financial support was provided principally by SANCOR through the kelp bed project, and the receipt of a CSIR post-graduate bursary by Miss $\mathrm{V}$ Stuart is gratefully acknowledged. R. C. Newell and M. I. Lucas are supported by funds from the Royal Society through a Senior Research Fellowship to R.C.N.

\section{LITERATURE CITED}

Calkins, G. N., Summers, F. M. (eds.) (1941). Protozoa in biological research, Columbia University Press, New York

Cammen, L. M. (1980). The significance of microbial carbon in the nutrition of the deposit-feeding polychaete Nereis succinea. Mar. Biol. 61: 9-20

Darnell, R. M. (1967). Organic detritus in relation to the estuarine ecosystem. In: Lauff, G. H. (ed) Estuaries. Amer. Assoc. Adv. Sci. pp. 376-382

Doetsch, R. N., Cook, T. M. (1973). Introduction to bacteria and their ecobiology, Medical and Technical Publishing Company, Lancaster, England

Driscoll, E. G. (1975). Sediment-animal-water interaction, Buzzards Bay, Massachusetts. J. mar. Res. 33(3): 275-302

Fenchel, T. (1972). Aspects of the decomposer food chains in marine benthos. (Sonderbd.) Sond. Verh. dt. zool. Ges. 65: $14-22$

Fuhrman, J. A. (1981). Influence of method on the apparent size distribution of bacterioplankton cells: Epifluorescence microscopy compared to scanning electron microscopy. Mar. Ecol. Prog. Ser. 5: 103-106

Gordon, D. C. (1966). The effects of the deposit-feeding polychaete Pectinaria gouldii on the intertidal sediments of Barnstable Harbor. Limnol. Oceanogr. 11: 327-332

Hatcher, B. G., Chapman, A. R. O., Mann, K. H. (1977). An annual carbon budget for the kelp Lammaria longicruris. Mar. Biol. 44: 85-96

Hobbie, J. E., Daley, R. T., Jasper, S. (1977). Use of Nuclepore filters for counting bacteria by fluorescence microscopy. Appl. environ. Microbiol. 33(5): 1225-1228

Johnson, R. G. (1974). Particulate matter at the sedimentwater interface in coastal environments. J. mar. Res. 33: $313-330$

Johnson, R. G. (1977). Vertical variation in particulate matter in the upper twenty centimetres of marine sediments. J. mar. Res. 35(2): 273-282

Johnston, C. S., Jones, R. G., Hunt, R. D. (1977). A seasonal carbon budget for a laminarian population in a Scottish sea loch. Helgoländer wiss. Meeresunters. 30: 527-545

Kreuter, J. N. (1976). Biodeposition by salt-marsh invertebrates. Mar. Biol. 35: 215-223

Linley, E. A. S., Newell, R. C. (1981). Microheterotrophic communities associated with the degradation of kelp debris. Proc. 15th Europ. Mar. Biol. Symp., Kiel. Meeresforschung (in press)

Linley, E. A. S., Newell, R. C., Bosma, S. A. (1981). Heterotrophic utilisation of mucilage released during fragmentation of kelp (Ecklonia maxima and Laminaria pallida). 1. Development of microbial communities associated with the degradation of kelp mucilage. Mar. Ecol. Prog. Ser. 4: $31-41$

Lucas, M. I., Newell, R. C., Velimirov, B. (1981). Heterotrophic utilisation of mucilage released during fragmentation of kelp (Ecklonia maxima and Laminaria pallida). 2. Differential utilisation of dissolved organic components from kelp mucilage. Mar. Ecol. Prog. Ser. 4: 43-55

Luria, S. E. (1960). The bacterial protoplasm: composition and organisation. In: Gunsalus, I. C., Stainier, R. Y (eds.) The bacteria, Vol. l. Academic Press, New York, pp. 1-34
Mangum, C. P. (1964). Activity patterns in metabolism and ecology of polychaetes. Comp. Biochem. Physiol. 11: 239-256

McMaster, R. L. (1967). Compactness variability of estuarine sediments: an in situ study. In: Lauff, G. H. (ed.) Estuaries. Am. Ass. Adv. Sci. 83: 1-757

Myers, A. C. (1977a). Sediment processing in a marine subtidal sandy bottom community. 1. Physical aspects. J mar. Res. 35(3): 609-632

Myers, A. C. (1977b). Sediment processing in a marine subtidal sandy bottom community. 2. Biological consequences. J. mar. Res. 35(3): 633-647

Newell, R. C. (1965). The role of detritus in the nutrition of two marine deposit-feeders, the prosobranch Hydrobia ulvae and the bivalve Macoma balthica. Proc. Zool. Soc. Lond. 144: $25-45$

Newell, R. C. (1979). Biology of intertidal animals, 3rd ed. Marine Ecological Surveys, Faversham, Kent

Newell, R. C., Field, J. G., Griffiths, C. L. (unpubl.). Energy balance and the significance of Micro-organisms in a kelp bed community

Newell, R. C., Lucas, M. I. (1981). The quantitative significance of dissolved and particulate organic matter released during fragmentation of kelp in coastal waters. Proc. 15th Europ. Mar. Biol. Symp., Kiel. Meeresforschung (in press)

Newell, R. C., Lucas, M. I., Linley, E. A. S. (1981). The rate of degradation and efficiency of conversion of phytoplankton debris by marine micro-organisms. Mar. Ecol. Prog. Ser. (in press)

Newell, R. C., Lucas, M. I., Velimirov, B., Seiderer, L. J (1980). Quantitative significance of dissolved organic loss. es following fragmentation of kelp (Ecklonia maxima and Laminaria pallida) Mar. Ecol. Prog. Ser. 2: 45-59

Nichols, F. H. (1974). Sediment turnover by a deposit-feeding polychaete. Limnol. Oceanogr 19(6): 945-950

Odum, E. P., Cruz, A. A., de la (1967). Particulate organic detritus in a Georgis salt marsh-estuarine ecosystem. In: Lauff, G. H. (ed). Estuaries. Publs Am. Ass. Advmt Sci. 83: 383-388

Payne, W. J. (1970). Energy yields and growth of heterotrophs. Ann. Rev. Microbiol. 24: 17-52

Rhoads, D. C. (1963). Rates of sediment reworking by Yoldia limatula in Buzzards Bay, Massachusetts and Long Island Sound. J. sedim. Petrol. 33: 723-727

Rhoads, D. C. (1967). Biogenic reworking of intertidal and subtidal sediments of Barnstable Harbor and Buzzards Bay, Massachusetts. J. Geol. 75: 461-476

Rhoads, D. C. (1973). The influence of deposit-feeding benthos on water trubidity and nutrient recycling. Am. J. Sci. 273: 1-22

Rhoads, D. C. (1974). Organism - sediment relations on the muddy sea floor. Oceanogr. Mar. Biol. Ann. Rev. 12: 263-300

Rhoads, D. C., Young, D. K. (1970). The influence of depositfeeding organisms on sediment stability and community trophic structure. J. mar. Res. 28: 150-178

Sieburth, J. Mc. N. (1976). Bacterial substrates and productivity in marine ecosystems. Ann. Rev. Ecol. Syst. 7: 259-285

Sorokin, Y. I., Kadota, H. (eds.) (1972). Techniques for the assessment of microbial production and decomposition in fresh waters. I. B. P. Handbook (23), Blackwell, Oxford

Strickland, J. D. H., Parsons, T. R. (1972). A practical handbook of seawater analysis, 2nd ed. Fish Res. Bd Can., Bull. 167

Stuart, V., Lucas, M. I., Newell, R. C. (1981). Heterotrophic utilisation of particulate matter from the kelp Laminaria pallida. Mar. Ecol. Prog. Ser. 4: 337-348 
Tenore, K. R. (1976). Food chain pathways in detrital feeding benthic communities: A review with new observations on sediment resuspension and detrital recycling. In: Coull, B C. (ed.) Marine science (6). Belle W. Baruch Libr. Univ. S. Carolina Press, Columbia, S.C., pp. 37-53
Troitsky, A. S., Sorokin, Y. I. (1967). On the methods of the calculation of the bacterial biomass in water bodies. Trans. Inst. Biol. Inland Waters. Acad. Sci. USSR 19: 85-90

This paper was presented by Professor R. C. Newell; it was accepted for printing on August 21, 1981 